\title{
Market Productivity of Single and Twin Bearing Karayaka Ewes
}

\author{
Mehmet Akif CAM ${ }^{1 *}$, Mustafa OFLAZ ${ }^{1}$, Koray KIRIKÇI ${ }^{2}$, \\ Ali Vaiz GARİPOĞLU ${ }^{1}$, Ercan SOYDAN ${ }^{3}$ \\ ${ }^{1}$ Department of Animal Science, Agricultural Faculty, Ondokuz Mayis University, 55200, Samsun, Turkey \\ ${ }^{2}$ Department of Animal Science, Agricultural Faculty, Ahievran University, 40100, Kırşehir, Turkey \\ ${ }^{3}$ Department of Agricultural Biotechnology, Agricultural Faculty, Ondokuz Mayis University, 55200, Samsun, Turkey \\ *İletişim (correspondence): e-posta makifcam@omu.edu.tr \\ Gönderim tarihi (Received): 09 Ağustos 2017; Kabul tarihi (Accepted): 09 Eylül 2017
}

\begin{abstract}
Karayaka sheep breed has high meat quality but low litter size. The sheep breeders believe that high prolificacy has a negative influence on lamb growth rate and survivability in this breed. This study was conducted to investigate twinning potential as well as the effect of birth type on birth weight, weaning weight, market productivity and survivability until weaning in Karayaka sheep during 2011-2012 years. And also, it was aimed to determine the repeatibility of twinning potential in selected ewes. A total of 60 ewes (3-4 aged) were collected from private sheep farms according to their own birth type and their mothers' birth type in 2010. Ewes born as twins were mated with rams born as twins. The conception rate, return rate, twinning rate, triplet rate and lamb mortality rate at weaning were determined as 100 , $16.22,52.25,3.60$ and $10.73 \%$, respectively, as mean of 2 years. The lamb weaning weights (90 days) according to birth type and gender were determined as $22.18 \pm 0.77$ (singles), $21.26 \pm 0.51$ (twins), $20.38 \pm 2.82 \mathrm{~kg}$ (triplets), $21.85 \pm 1.80$ (males) and $20.70 \pm 0.83 \mathrm{~kg}$ (females) While lamb birth weights were affected by birth type, the weaning weights were affected by gender $(\mathrm{P}<0.05)$. Generally, market productivities of multiple born ewes were higher than those of single born ewes ( $21.30 \mathrm{vs} 37.18 \mathrm{~kg}, \mathrm{P}<0.001)$. Consequently, this study shows that in selected ewes in the direction of twinning, the twin birth tendency is high.
\end{abstract}

Keywords: Fecundity, litter size, market productivity, flock productivity, reproduction, selection, Karayaka sheep

Tekiz ve İkiz Doğuran Karayaka Koyunlarda Pazar Üretkenliği

\section{$\ddot{O} \mathbf{z}$}

Karayaka ırkı düşük döl verimli, fakat yüksek et kalitesine sahiptir. Bu ırktan koyun yetiştiricileri, yüksek döl veriminin kuzu büyüme oranı ve kuzu yaşama gücü üzerinde olumsuz etkilere sahip olduğuna inanmaktadırlar. Bu çalışma, Karayaka koyun ırkında 2011 ve 2012 yılarında ikizlik potansiyelini araştırmak, kuzularda doğum tipinin kuzu doğum ve sütten kesim ağırlığına, doğum tipinin sürü üretkenliğine ve sütten kesime kadar kuzu yaşama gücüne etkilerini belirlemek amacı ile planlanmıştır. Toplam 3-4 yaşlarında 60 koyun kendilerinin ve analarının doğum tipine göre 2010 yılında özel saf Karayaka koyun işletmelerinden seçilmiştir. İkiz olarak doğuran koyunlar, ikiz olarak doğmuş koçlarla çiftleştirilmiştir. Gebelik, geri dönme, ikizlik ve üçüzlük oranları ile sütten kesimde ölü doğum oranı birbirini takibeden iki yılın ortalaması olarak sırasıyla 100, 16.22, 52.25, 3.60 ve \%10.73 olarak belirlenmiştir. Doğum tipine ve cinsiyete göre 90 günlük sütten kesim ağırlıkları tekizler için $22.18 \pm 0.77 \mathrm{~kg}$, ikizler için $21.26 \pm 0.51 \mathrm{~kg}$, üçüzler için $20.38 \pm 2.82 \mathrm{~kg}$, erkekler için $21.85 \pm 1.80$ ve dişiler için $20.70 \pm 0.83 \mathrm{~kg}$ olarak belirlenmiştir. Kuzu doğum ağırlıkları kuzu doğum tipinden, kuzu sütten kesim ağırlıkları ise cinsiyetten etkilenmiştir $(\mathrm{P}<0.05)$. Genel olarak, ikiz doğuran koyunların pazar üretkenliği tekiz doğuranlardan daha yüksek bulunmuştur (21.30 karşın $37.18 \mathrm{~kg}, \mathrm{P}<0.001)$. Sonuç olarak, bu çalışma ikizlik temelinde seçilen koyunlarda ikiz doğum yönündeki eğilimin daha yüksek olduğunu ortaya koymuştur.

Anahtar Kelimeler: Döl verimi, batın büyüklüğü, pazar üretkenliği, sürü üretkenliği, üreme, seleksiyon, Karayaka koyunu

\section{Introduction}

Although indigenious sheep breeds have adaptability to harsh environment conditions and resistance to diseases, they have been exposed to struggle for life due to their low prolificacy and crossbreeding pressure. Low prolific breeds could be improved using the variations between and within herds for the selection for prolificacy. The most important profitability component in mutton production is lamb yield or reproductive performance all over the world. Reproductive performance in ewe flock can be defined as i) the number of lambs weaned or marketed per 100 ewes joined to ram, ii) total lamb live weight at weaning or iii) the number of lambs marketed per 100 ewes joined to ram (De Graaf, 2010). Although twin lambs are 
not preferred due to high lamb mortality (especially in low prolific breeds) and also they need more care than singleton lambs, experienced breeders prefer more lambs to earn more profit (Amer and Bodin, 2006).

The main factors affecting the profitability of mutton production are prolificacy rate, litter size, offspring survivability, feed conversion rate, feed price, meat price, investment expenditure, redemption and labor. Of these, the most important is prolificacy rate. Therefore, all the breeding programs involve the improving of prolificacy rates. On the other hand, it was reported that there were positive correlations $(0.84-0.87)$ between weaning weights of lambs and twinning rate (Amer and Bodin, 2006). However, increase in the litter size also leads to increase in triplet lambing percentages (Amer et al., 1998; Amer and Bodin, 2006). Also, triplets have higher mortality rates than single and twin born especially in low prolific breeds.

Crossbreeding is a widespread method used for increasing lambing rate and meat production of low profilic breeds such as Karayaka (Olfaz, 1997; Atasoy et al., 2003; Akçapınar et al., 2005; Balci and Karakas, 2007; Ulutas et al., 2008). On the other hand, crossbreed animals face to serious adaptation problems including long walking and under hill station condition. Therefore, there is a limited opportunity to use foreign breeds to improve the lamb production and meat yield capacity of Karayaka breed. Currently purebred selection of regional breeds is the usual method applied for the genetic improvement (Unal et al., 2003; Olfaz et al., 2005). Selection is slow and time-consuming and also it is hard to get desired results by using selection, especially for low heritability traits (Boujenane et al., 2013, 2015). Litter size and fecundity are generally used for selection criteria for reproductive traits (Schmidová et al., 2014). However, due to low heritability (approximately 0.10) selection response for litter size usually is not substantial and allow selection response only up to $2 \%$ / year from simple mass selection (Notter, 2008; Schmidová et al., 2015). However, selection for litter size has been included in many breeding programs all over the world (Maxa et al., 2007; Schmidova et al., 2014). Increasing the number of lamb per ewe can be improved by producing more lamb at slaughter age. Amer et al. (1998) reported that selection for increasing prolificacy in sheep leads to a higher average litter size. The most intriguing result of the present study is the achievement of repetability for low heritable traits (i.e. fertility) in selection schemes. But, genetic improvements are very slow in increasing the twinning tendency and there were low correlations of 0.21 and 0.31 between the twinning tendency of the ewes and that of their daughter. However, the simple and easiest way to increase the twinning tendency is to increase the twinning rate by using genetic selection (Amer and Bodin, 2006). On the other hand, there are two major parameters to improve genetic and phenotypic traits in all domestic animals under the optimal environmental conditions: selection and mating (Bourdon, 1997). The native breeds, which have high adaptive capacity, should be protected against the pressure of crossing with high yield breeds. In present study, it was aimed to build a flock composed of twin born and twin bearing ewes and afterwards to determine the repeatability of reproduction traits (especially twinning tendency) in this flock. Also, it was aimed to determine market and flock productivity in ewes selected for twinning.

\section{Materials and Method}

\section{Study site and animals}

The study was carried out at Research and Application Farm (RAF, $41.21^{\circ} \mathrm{N}$ and $36.15^{\circ} \mathrm{E}$ ) of Agricultural Faculty of Ondokuz Mayis University in order to determine the prolificacies and market productivities of single and multiple bearing ewes at indigenous Karayaka sheep breed. Sixty ewes of 3-4 years old were selected from ten private farms in Samsun, Ordu and Tokat provinces in the late of 2009 and early of 2010. Furthermore, two 2 years old stud rams were selected. Before ewes and rams were brought to RAF, blood sample were collected and analyzed for brucella. Ewes with negative results were transported to RAF.

Ewes were grazed daily between 4.30 AM and 22.00 PM on natural vegetation. In addition to grazing, the animals were provided with concentrate mixture (approximately $350 \mathrm{~g} /$ day/head) for three weeks during premating, mating and at two months of the late of gestation. NRC (1985) standards were taken into account for meeting nutrient requirements. Lambs were housed with their mothers until weaning (90 days) and they had free access to mineral mixture and water.

Estrus was determined by teaser rams two times in a day during breeding season in 2010 and 2011. Ewes were mated under controlled conditions (hand mating) in single-sire pens in breeding season in September and October. Ewes showed signs of estrus had been housed 
with rams in the same pen for $12 \mathrm{~h}$ and all matings were recorded. Each sire was mated with equal amounts of females. The reproduction traits included the number of lambs born per ewe lambing (litter size), lambs born per ewe mated (fecundity), pre-weaning and weaning lamb survival, number of alive lambs at weaned per ewe lambing (litter size at weaned) and fertility (lambed or not).

The body weights of mating animals were recorded at mating and parturition. After parturition, all lambs were marked with ear tag and remained with their dams for 24 $\mathrm{h}$ until weaning and lamb body weights were recorded at birth and marketing age or weight (market time).

\section{Statistical analysis}

Lambing ewes were grouped according to their bearing types at parturition. There were no significant differences in terms of body weight and body condition score between multiple and singleton lambing ewes, and among the multiple born lambs' birth weights and the lack of numbers multiple bearing ewes and lambs. For this reason, these data were pooled. Also, there were no significant differences in terms of ewe body weights and the mentioned traits between years. Conception rate, lambing percentage, return rate, fecundity (the number of lambs per ewe joined), prolificacy or litter size (the average number of lambs per ewe lambing), the survivability of lambs at birth and weaning were analyzed using descriptive statistics with crosstabs and Chi-Squares.

Ewe body weights at mating and postpartum time were analyzed with GLM procedure according to bearing type. Lamb birth weight and weaning weight were evaluated with birth type and gender as a fix factor and dam weight at postpartum used covariate in General linear model (GLM) procedure of the SPSS pocket programs (V.24, 2016). All lambs were deprived from food at night and weighed at morning with empty stomach. At marketing time there was a \pm 10 days deviation between lambs, for this reason interpolation was applied for data, and adjusted data were used in statistical process.

Market productivity was calculated as total marketing weights of lambs born to single and twin bearing ewes. Triplet bearing lambs and ewes were evaluated with twin bearing ewes and twin born lambs. Market productivity was calculated for single and multiple bearing ewes as follows:

1. Total weights of the single born lambs at market time/ total single bearing ewes or ewes joined to ram.

2. Total weights of the multiple born lambs at market time / total multiple bearing ewes or ewes joined to ram.

Flock productivity was calculated as the total lambs weights per ewes to joined in contradistinction to some previous studies (Earle et al., 2017) This parameter can be calculated separately for single and multiple bearing ewes. But, as there are not any nonpregnant or nonbearing ewes, this parameter (flock productivity) was found equal to market productivity.

In this study all the ewes were fertile and pregnant, therefore, the denominator accepted as total single or multiple bearing ewes.

\section{Results}

Data related to fertility rate, return rate and fecundity at lambing and at weaning (90 days) and lamb mortality during weaning period are presented in Table 1 . The values related to fertility rate and return rate of ewes selected for twinning were $100 \%$ and $16.67 \%$, and $100 \%$ and $15.68 \%$ in 2010 and 2011, respectively. One of the stillborn lambs was belong to single borning ewe and three of them were belong to triplet bearing ewes in 2011 . In 2012, one of the still born lambs was belong to triplet bearing ewes. Bearing type of ewes affected fecundity at lambing $(\chi 2=4.342, \quad \mathrm{P}=0.114$ and $\chi 2187=3.715$, $\mathrm{P}=0.156)$ and market (weaning) times $(\chi 2=4.530$, $\mathrm{P}=0.104$ and $\chi 2188=3.150, \mathrm{P}=0.207)$ in two consecutive years. When data combined for years there were significant effect $(\chi 2=8.276, \mathrm{P}=0.016$ and $\chi 2190=7.562$, $\mathrm{P}=0.023)$ on fecundity between single, twin and triplet bearing ewes for parturition and market time, respectively.

Data related to lamb growth and survivability characteristics are presented Table 2. Body weight gains form birth to weaning time were higher in single born lambs and male lambs than that of twin and female born lambs. The multiple born $(195.5 \pm 5.80 \mathrm{~g})$ and female $(192.1 \pm 7.37 \mathrm{~g})$ lambs have gained less body weight than single born $(206.19 \pm 9.05 \mathrm{~g})$ and male lambs $(220.2 \pm 13.08$ g). 
Table 1. Reproductive performances of selected for twin bearing ewes.

\begin{tabular}{|l|c|c|}
\hline Reproductive parameters & 2010 & 2011 \\
\hline Eve number of joined to ram (n) & 60 & 51 \\
\hline Conception and birth rates (\%) & $100(60 / 60)$ & $100(51 / 51)$ \\
\hline Still birth rate (\%) & $3.33(2 / 60)$ & $1.96(1 / 51)$ \\
\hline Twinning rate (\%) & $53.3(32 / 60)$ & $50.98(26 / 51)$ \\
\hline Triplet rate (\%) & $3.3(2 / 60)$ & $3.92(2 / 51)$ \\
\hline Return rate (\%) & $16.67(10 / 60)$ & $15.68(8 / 51)$ \\
\hline Ewe number of estrus (\%) & $100(60 / 60$ & $100(51 / 51)$ \\
\hline Fecundity at parturition & $1.53(92 / 60)$ & $1.57(80 / 51)$ \\
\hline Fecundity at market time & $1.42(85 / 60)$ & $1.45(74 / 51)$ \\
\hline Lamb mortality at parturition & $4.17(4 / 96)$ & $1.23(1 / 81)$ \\
\hline Lamb mortality at market time & $11.46(11 / 96)$ & $8.64(7 / 81)$ \\
\hline Ewe body weight at mating $(\mathrm{kg})$ & $45.6 \pm 2.57$ & $44.5 \pm 2.28$ \\
\hline Ewe body weight at parturition $(\mathrm{kg})$ & $53.8 \pm 3.69$ & $52.7 \pm 3.71$ \\
\hline
\end{tabular}

Table 2. Body weights and survivability of lambs according to birth type and gender (Mean $\pm \mathrm{Se}$ )

\begin{tabular}{|c|c|c|c|c|c|}
\hline 2011 & \multicolumn{4}{|c|}{ Lamb body weight (kg) } & \multirow{2}{*}{$\begin{array}{c}\text { Survivability } \\
(\%)\end{array}$} \\
\hline Birth type/ Gender & $\mathbf{n}$ & Birth & $\mathrm{n}$ & Weaning & \\
\hline \multirow{3}{*}{$\begin{array}{l}\text { Single } \\
\text { Male } \\
\text { Female }\end{array}$} & 26 & $3.8 \pm 0.11$ & 23 & $23.6 \pm 0.98$ & \multirow{3}{*}{$\begin{array}{l}88.46(23 / 26) \\
85.71(12 / 14) \\
91.67(11 / 12)\end{array}$} \\
\hline & $14-1 *$ & 3.85 & 12 & 24.41 & \\
\hline & 12 & 3.73 & 11 & 22.59 & \\
\hline \multirow{3}{*}{$\begin{array}{l}\text { Twin } \\
\text { Male } \\
\text { Female }\end{array}$} & 64 & $3.5 \pm 0.07$ & 60 & $23.3 \pm 0.62$ & \multirow{3}{*}{$\begin{array}{l}93.75(60 / 64) \\
96.97(32 / 33) \\
90.32(28 / 31)\end{array}$} \\
\hline & 33 & 3.51 & 32 & 24.09 & \\
\hline & 31 & 3.41 & 28 & 22.47 & \\
\hline Triplet (F/M; (4-1/2-2)* & $3 / 0$ & $2.9 \pm 0.40$ & 2 & $24.7 \pm 3.37$ & $33.33(2 / 6)$ \\
\hline \multirow{3}{*}{$\begin{array}{l}\text { Male } \\
\text { Female } \\
\text { Lamb Mortality }\end{array}$} & 49 & $3.6 \pm 0.09$ & 44 & $24.3 \pm 0.81$ & $89.80(44 / 49)$ \\
\hline & 47 & $3.4 \pm 0.15$ & 41 & $23.3 \pm 1.24$ & $87.23(41 / 47)$ \\
\hline & & $4.17(4 / 96)$ & & $11.46(11 / 96)$ & $88.54(85 / 96)$ \\
\hline 2012 & \multicolumn{4}{|c|}{ Lamb body weight (kg) } & \multirow{2}{*}{$\begin{array}{c}\text { Survivability } \\
(\%)\end{array}$} \\
\hline & $\mathbf{n}$ & Birth & n & Weaning & \\
\hline \multirow{3}{*}{$\begin{array}{l}\text { Single } \\
\text { Male } \\
\text { Female }\end{array}$} & 23 & $3.7 \pm 0.11$ & 22 & $21.1 \pm 1.08$ & \multirow{3}{*}{$\begin{array}{l}95.65(22 / 23) \\
100.00(13 / 13) \\
90.00(9 / 10)\end{array}$} \\
\hline & 13 & 3.71 & 13 & 22.65 & \\
\hline & 10 & 3.47 & 9 & 19.50 & \\
\hline \multirow{4}{*}{$\begin{array}{l}\text { Twin } \\
\text { Male } \\
\text { Female } \\
\text { Triplet }(\mathrm{F} / \mathrm{M}) *[4 /(2-1)]\end{array}$} & 52 & $3.2 \pm 0.07$ & 49 & $18.6 \pm 0.74$ & \multirow{3}{*}{$\begin{array}{l}94.23(49 / 52) \\
91.67(22 / 24) \\
96.43(27 / 28) \\
\end{array}$} \\
\hline & 24 & 3.18 & 22 & 18.59 & \\
\hline & 28 & 3.29 & 27 & 18.65 & \\
\hline & $4 / 1$ & $2.9 \pm 0.22$ & $3 / 0$ & $18.9 \pm 2.82$ & $50.00(3 / 6)$ \\
\hline \multirow{4}{*}{$\begin{array}{l}\text { Overall } \\
\text { Male } \\
\text { Female } \\
\text { Lamb Mortality }\end{array}$} & 81 & & 74 & & $91.36(74 / 81)$ \\
\hline & 39 & $3.3 \pm 0.14$ & 35 & $20.4 \pm 1.80$ & $89.74(35 / 39)$ \\
\hline & 42 & $3.3 \pm 0.10$ & 39 & $18.7 \pm 1.03$ & $92.86(39 / 42)$ \\
\hline & & $1.23(1 / 81)$ & & $8.64(7 / 81)$ & $91.36(74 / 81)$ \\
\hline \multirow{2}{*}{$\begin{array}{l}\text { Overall } \\
\qquad(2011+2012) \\
\end{array}$} & & \multicolumn{3}{|c|}{ Lamb body weight (kg) } & \multirow{2}{*}{$\begin{array}{c}\begin{array}{c}\text { Survivability } \\
(\%)\end{array} \\
\end{array}$} \\
\hline & $\mathbf{n}$ & Birth & n & Weaning & \\
\hline \multirow{3}{*}{$\begin{array}{l}\text { Single } \\
\text { Male } \\
\text { Female } \\
\end{array}$} & 49 & $3.8 \pm 0.08 \mathrm{a}$ & 45 & $22.2 \pm 0.77$ & \multirow{3}{*}{$\begin{array}{l}91.84(45 / 49) \\
92.59(25 / 27) \\
90.91(20 / 22)\end{array}$} \\
\hline & 27 & $3.8 \pm 0.11$ & 25 & $23.5 \pm 1.06$ & \\
\hline & 22 & $3.8 \pm 0.11$ & 20 & $20.89 \pm 1.06$ & \\
\hline \multirow{3}{*}{$\begin{array}{l}\text { Multiple** }^{* *} \\
\text { Male } \\
\text { Female }\end{array}$} & 123 & $3.3 \pm 0.05 b$ & 114 & $21.2 \pm 0.49$ & \multirow{3}{*}{$\begin{array}{l}92.68(114 / 123) \\
94.74(54 / 57) \\
90.91(60 / 66)\end{array}$} \\
\hline & 57 & $3.4 \pm 0.68$ & 54 & $21.8 \pm 0.73$ & \\
\hline & 66 & $3.3 \pm 0.07$ & 60 & $20.7 \pm 0.66$ & \\
\hline \multirow{4}{*}{$\begin{array}{l}\text { Overall } \\
\text { Male } \\
\text { Female } \\
\text { Lamb mortality }\end{array}$} & 177 & & 159 & & $89.83(159 / 177)$ \\
\hline & 88 & $3.6 \pm 0.06$ & 79 & $22.6 \pm 0.66 \mathrm{~A}$ & $89.77(79 / 88)$ \\
\hline & 89 & $3.5 \pm 0.06$ & 80 & $20.8 \pm 0.62 \mathrm{~B}$ & $89.89(80 / 89)$ \\
\hline & & $2.82(5 / 165)$ & & $10.12(18 / 165)$ & \\
\hline
\end{tabular}

*: stillborn, **: Include twin and triplets, SEM: standard error of mean, n: number of lambs, Means with different superscript are significantly different $(\mathrm{a}, \mathrm{b} \mathrm{P}<0.05$ and $\mathrm{A}, \mathrm{B} \mathrm{P}<0.0001)$ respectively in each column, $\mathrm{n}$ : the number of born lambs 
Lamb mortality rates in triplet born lambs were higher than those in other birth types both at birth and market time $(\chi 2=32.859, \mathrm{P}<0.001)$. One half or more than one half of triplet born lams were died. There were not significant differences $(\mathrm{P}>0.05)$ between single and twin born lambs' survival rate within and between years at birth and market time (Table 2). In this study, four triplet (12 lambs) birth occurred and 4 and 7 of them were died at parturition and weaning time, respectively. It is noteworthy that two female lambs and one male lamb born to death. Market productivity values are presented in Figure 1. Multiple bearing ewes contribute higher profit to sheep owner $(\mathrm{P}<0.001)$ than single bearing ewes. When combined data of two years were taken into consideration it was shown that lamb weights per multiple bearing ewes were significantly higher $(\mathrm{P}<0.001$ and 37.18 vs $21.30 \mathrm{~kg})$. The birth type was shown to have significant effect on market productivity in two consecutive years.

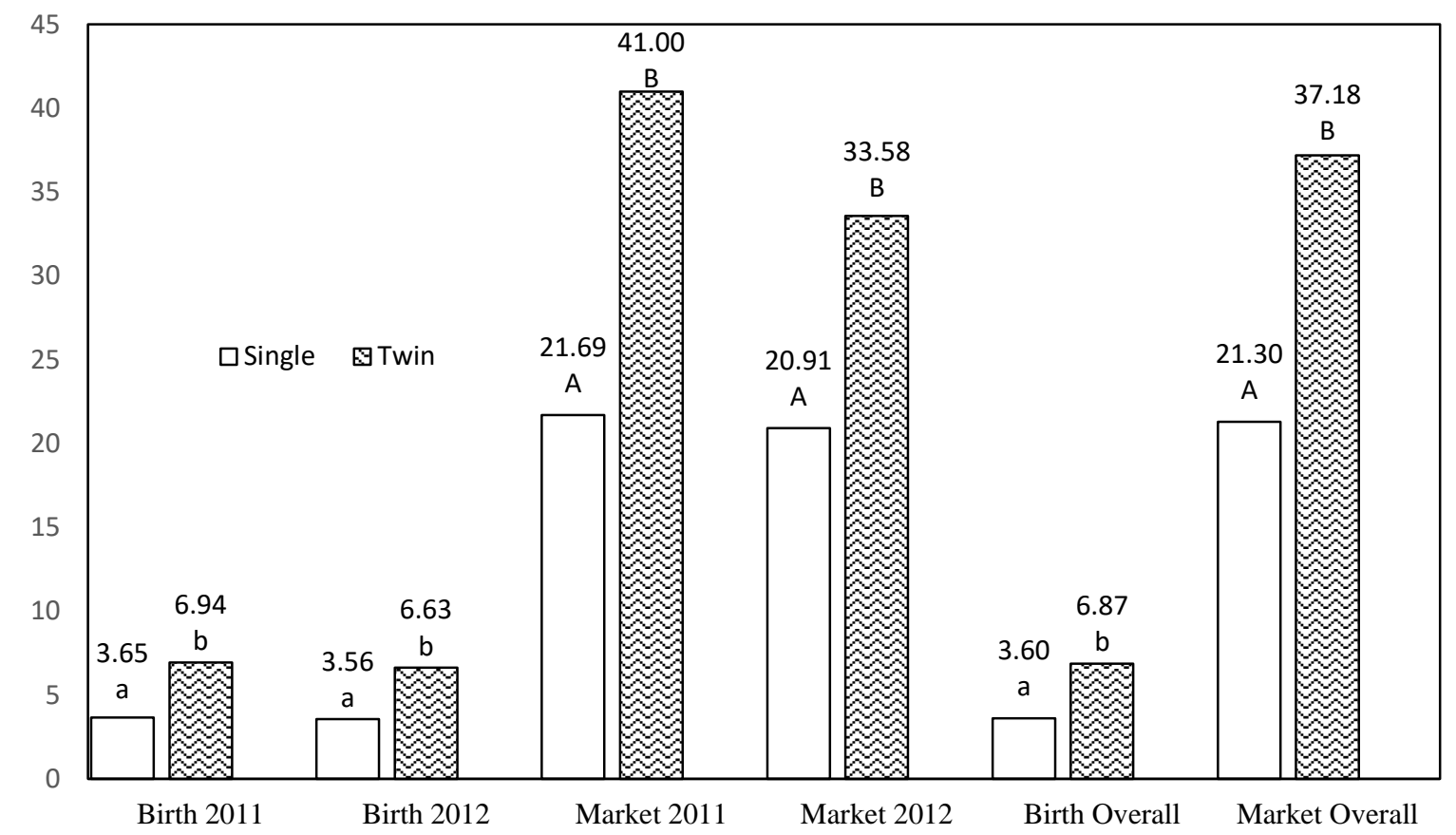

Figure 1. Market productivity for single and twin bearing ewes

There were significant differences between twin bearing and single bearing ewes both birth productivity $(\mathrm{a}, \mathrm{b} ; \mathrm{P}<0.05)$ and market productivity $(\mathrm{A}, \mathrm{B} ; \mathrm{P}<0.001)$

\section{Discussion}

There was no study related to litter size and the market productivity of Karayaka sheep. The tendency for repeating twin born in selected ewes was 55 percent, although they were twin born and also, they gave birth to twin lambs. This has been observed to occur at lower levels (20-25\%) in the offspring of selected animals (unpublished data). This suggests that it is difficult to achieve progress in features with low inheritance by selection.

Market productivity which is a major criteria for profitability in sheep production. It contains lamb body weight, number of marketed lambs, the number of mated ewes, gestation rate, fertility rates and lambing rates.

Conception rate, fertility rate and lambing rate in present study were dramatically (100\%) high. These mentioned rates could be varied from herd to herd (Michels et al., 2000) according to rearing conditions and management practices. These high rates can be attributed to the fact that the ewes were selected for high litter size. Lamb survivability is another factor that affects market productivity. The survivability of single $(91.84 \%)$ and twin bearing lambs $(93.97 \%)$ were high, but that of triplet lambs was very low (41.67\%) (Bradford, 1985). Triplet birth rate is low in Karayaka breed and this birth type is not preferred by farmers. Lamb survivability in multiple born lambs has been affected by many genetic factors (maternal effect, birth weight and birth type) and environmental factors (competition and management) (Greenwood et al., 1998; Ceyhan et al., 2010). In our study, there were significant differences between single and twin lamb birth weights (Table 2). Lamb survivability might be affected by a factor apart from 
lamb birth weight. Therefore, especially low prolific sheep breed owners hesitate to have higher number of twin bearing ewes due to low survivability and growth performance (Amer et al, 1998; Cam, 2016).

Under present study conditions, multiple bearing rates were 56.7 and $54.9 \%$ for two consecutive years which are dramatically higher than previously reported levels of $8 \%$ (Olfaz et al., 2005) and 19\% (Ulutas et al., 2010). Although there is a demand for increasing litter size, it is difficult to meet this demand as the heritability of this trait is low (Van Vleck, et al., 1991; Schmidová et al., 2014; 2015). In present study, selecting ewes for twin bearing had a positive effect on litter size. Also, it is known that ovulation rate and litter size are determined by a gene located on sixth autosomal chromosome in some sheep breeds such as Booroola Merino (Mishra et al., 2009). When we take into account the plenty of research related to the gene effects on the reproductive traits such as fecundity and prolificacy of sheep breeds, it remains to elucidate whether Karayaka breed carries such a gene or not for further studies.

In the study, the rate of triplet bearing ewes was $3.60 \%$ and less than a half of triplet lambs were alive. Therefore, it can be said that triplet born type, but not twin born type, is problematic for Karayaka sheep breed. These results agree with the statements of Amer et al., (1998) and San Cristobal-Gaudy, et al., (2001) who reported that triplet born type can be problematic as they have lower survival rates and need more care.

Our results show that there is a moderate variation in terms of birth type in Karayaka breed. On the other hand, most of Karayaka breed owners complain that the survivability of twin born lambs are lower than singles, but our study showed that this is not true. Although, multiple born lambs generally have low body weight and growth performance (Amer et al., 1998), multiple litters have been shown to increase ewe prolificacy in herd (Earle et al., 2016). The results obtained in this study were in accordance with these reports. From the stand point of farm's profitability, prolificacy (the number of lambs per lambing ewes) and fecundity (the number of lambs per breeding ewes) at market time are crucial component of profitability and herd management (Michels et al., 2000). From this point of view, lambs' growth performance and daily body weight gain according to birth types are important. In our study, the body weight and daily body weight gain of single and twin lambs at market time were numerically, not statistically, different (Table 2). However, the contribution of twin bearing ewes to market productivity was found higher (33.58 vs 20.91; Table 1 and Figure 1). This result was supported by Wolfová et al., (2011) who reported that improving reproductive traits has higher economic significance than increasing daily weight gain in sheep. Although twin lambs had low birth weight and low growth performance due to competition, their contribution to farm profit (or flock productivity) were high. The birth and body weight of lambs in this study was in accordance with some previous studies (Atasoy et al., 2003; Unal et al., 2003; Ulutas et al., 2008; 2010).

Unfortunately, we could not calculate the genetic parameter related to litter size because of insufficient ewe numbers, but our study sets a precedent for studies which will be conducted with the aim of aiming to increase lamb yield in flock. Consequently, it could be said that the present study indicates that selecting ewes for twin lambing is the best criterion for enhancing lamb yield which has a very low heritability.

\section{Conclusion}

Consequently, it was shown that, under the conditions of the present study, the repeatibility of twinning in ewes selected for twinning was at moderate level $(55 \%)$ and viability of twin born lambs was high. The offspring yield capacity of Karayaka sheep breed could be improved genetically and environmentally by selections for twinning in spite of the fact that the heritability of fertility is low. Additionally, unlike postulated by breeders, market productivity or farm productivity in multiple bearing ewes were higher than singleton bearing ewes, therefore, non prolific herd (such as Karayaka breed) owners might be went back on their thoughts about twin bearing ewes.

\section{Acknowledgement}

The work was supported by Ondokuz Mayis University Project Management Office (PYO) with the name of "Establishing Karayaka Sheep Elite Herd as a Local Genetic Resources" and the approval code "PYO. ZRT.1906.009.011”. 


\section{References}

Akcapinar H, Unal N, Atasoy F. 2005. The Effects of early age mating on some production traits of Bafra (Chios $\mathrm{x}$ Karayaka $B_{1}$ ) Sheep. Turkish Journal of Veterinary and Animal Sciences, 29: 531-536.

Amer PR, Bodin L. 2006. Quantitive genetic for selection for twinning rate in ewes. Proceedings of the New Zealand Society of Animal Production, 66: 429-433.

Amer PR, McEwan JC, Dodds KG, Davis GH. 1998. Economic values for ewe prolificacy and lam survival in New Zealand. Livestock Production Science, 58: 7590.

Atasoy F, Unal N, Akcapinar H, Mundan D. 2003. Some production traits of Karayaka and Bafra (Chios $\mathrm{x}$ Karayaka $B_{1}$ ) Sheep. Turkish Journal of Veterinary and Animal Sciences, 27: 259-264.

Balc1 F, Karakas E. 2007. The effect of different slaughter weights on the fattening performance, slaughter and carcass characteristics of male Karayaka lambs. Turkish Journal of Veterinary and Animal Sciences, 31: 25-31.

Bradford GE. 1985. Selection for Litter Size. In Genetics of Reroduction in Sheep, pp. 3-18. Ed. Land RB, Robinson OW. Butterworths, London.

Boujenane I, Chikhi A, Sylla M, Ibnelbachyr M. 2013. Estimation of genetic parameters and genetic gains for reproductive traits and body weight of D'man ewes. Small Ruminanat Research. 113: 40-46.

Boujenane I, Chikhi A, Ibnelbachyr M, Mouh FZ. 2015.Not in the text Estimation of genetic parameters and maternal effects for body weight at different ages in D'man sheep. Small Ruminanat Research. 130: 40-46.

Bourdon RM. 1997. Understanding Animal Breeding. Prentice Hall Inc. 524p. London. UK.

Ceyhan A, Sezenler T, Yıldırır M, Erdogan I. 2010. Reproductive performance and lamb growth characteristics of Ramlic sheep. Kafkas Üniversitesi Veteriner Fakültesi Dergisi, 16: 213-216.

Cam MA. 2016. Personel interviews with sheep breeders.

De Graaf SP. 2010. Reproduction. Edit Cottle DJ. International Sheep and Wool Handbook. Nottingham University Pres. 755p. UK.

Earle E, McHugh N, Boland TM, Creighton P. 2016. Effect of ewe prolificacy potential and stocking rate on primiparous flock performance. Small Ruminant Research. 143: 53-60.

Earle E, McHugh N, Boland TM, Creighton P. 2017. Effect of ewe prolificacy potential and stocking rate on ewe and lamb performance in a grass-based lamb production system. Journal of Animal Science, 95: 154-164.

Greenwood PL, Hunt AS, Hermanson JW, Bell AW. 1998. Effects of birth weight and postnatal nutrition on neonatal sheep: II. Body growth and composition, and some aspects of energetic efficiency. Journal of Animal Science, 76: 2354-2367.

Maxa J, Norberg E, Berg P, Pedersen J. 2007. Genetic parameters for growth traits and litter size in Danish Texel, Shropshire, Oxford Down and Suffolk. Small Ruminant Research, 68: 312-317.

Michels H, Decuypere E, Onagbesan O. 2000. Litter size, ovulation rate and prenatal survival in relation to ewe body weight: genetic review. Small Ruminant Research, 38: 199-209.

Mishra AK, Arora AL, Kumar S, Prince LLL. 2009. Studies on effect of Booroola (FecB) genotype on lifetime ewes' productivity efficiency, litter size and number of weaned lambs in Garole $\times$ Malpura sheep. Animal Reproduction Science, 113: 293-298.

Notter DR. 2008. Genetic aspects of reproduction in sheep. Reproduction in Domestic Animals, 43 Suppl. 2: 122128.

NRC. 1985. Nutrient Requirement of Sheep. National Academi Pres. 2101. Constitution Avenue, NW, Washington, DC 20418, 100s.

Olfaz M. 1997. Utilization possibilities from common and exotic races to improve meat yields and carcass characteristics of Karayaka sheep. OMU Institute of Science and Technology. PhD Thesis.

Olfaz M, Ocak N, Erener G, Cam MA, Garipoglu AV. 2005. Growth carcass and meat characteristics of Karayaka growing rams, fed sugar beet pulp partially substituting for grass hay as forage. Meat Sciece, 70: 7-14.

San Crostobel-Gaudy M, Bodin L, Elsen JM, Chevalet C. 2001. Genetic components of litter size variability in sheep. Genetics Selection Evolution, 33: 249-271.

Schmidová J, Milerski M, Svitaková A, Vostry' L, Novotná A. 2014. Estimation of genetic parameters for 
litter size in Charollais, Romney, Merinolandschaf, Romanov, Suffolk, Sumava and Texel breeds of sheep. Small Ruminant Research, 119: 33-38, 2014.

Schmidová J., Milerski M, Svitaková A, Vostry' L. 2015. Effects of service ram on litter size in Romanov sheep. Small Ruminant Research, 141: 56-62.

SPSS. Headquarters, (Release 24.0.0). 2016. 233 S. SPSS Inc., Wacker Drive, 11th flor Chicago, Illinois 60606, USA.

Ulutas Z, Aksoy Y, Sirin E, Saatci M. 2008. Introducing the Karayaka sheep breed with its traits and influencing factors. Pakistan Journal of Biological Sciences, 11: 1051-1054.

Ulutas Z, Sezer M, Aksoy Y, Sirin E, Sen U, Kuran M, Akbas Y. 2010. The effect of birth types on growth curve parameters of Karayaka lamb. Journal of Animal and Veterinary Advances, 9: 1384-1388.

Unal N, Atasoy F, Akcapinar H, Erdoğan M. 2003. Fertility traits, survival rate and growth characteristics of Karayaka and Bafra (Chios x Karayaka $B_{1}$ ) Genotypes. Turkish Journal of Veterinary and Animal Sciences, 27: 265-272.

Wolfová M, Wolf J, Milerski M. 2011. Economic weights of production and functional traits for Merinolandschaf, Romney, Romanov and Sumavska sheep in the Czech Republic. Small Ruminant Research, 99: 25-33.

Van Vleck LD, Gregory KE, Echternkamp SE. 1991. Ovulation rate and twinning rate in cattle: Heritabilities and genetic correlation. Journal of Animal Science, 69: 3213. 